\title{
Review of Willie Henderson's The origins of David Hume's economics. London and New York: Routledge, 2010, 228 pp.
}

\author{
CHRISTOPHER J. BERRY \\ University of Glasgow
}

The "origins" in the title refers narrowly to the link between Hume's Political discourses (1987 [1752]) and A treatise of human nature (2002 [1739-1740]). As this locution indicates Henderson wants to argue for a unity and continuity in Hume's thinking-hence a detailed discussion of the "Abstract" (of A treatise of human nature) and a chapter on the two Enquiries (Hume 1999 [1748]; and 1998 [1751]). However, he argues that notwithstanding this coherence Hume deliberately changed his "textual strategy" and embarked on what Henderson calls a "rhetorical turn" (Henderson 2010, 4, et passim). In the context of this book's own "strategy" the way this argument is executed produces an odd outcome. Henderson is careful to advertise that this is not a book of "advanced scholarship" but is a "general book" intended "to help those new to Hume" (pp. xvi, 20, xv), yet the first third of the book is devoted to a discussion of textual analysis in general and of some passages of Hume in particular. The more general analysis goes on at some length about the various meaning of "summarization" and "selection", citing in the process some standard histories of economics. It is questionable whether Henderson's intended audience is as concerned as he is with this issue.

Henderson's own commitment to textualism is relatively unreflective. There is not here any excursus into Derridean or Foucauldian concerns about "authorship" (merely some occasional second-hand references to post-structuralism) nor is there any acknowledgement of the Cambridge School's and their critics' deliberations on intentionality. This unreflectiveness does reveal itself in some naivety, as when he states "meaning is rarely given in a sentence, being rather constructed within a sweep of sentences in a surrounding discourse" (p. 36). He also does not subscribe to this dictum wholeheartedly since he is able to declare that Hume's admiration for commercial society is exhibited "at sentence level" (p. 89). At the heart of Henderson's textualism is what he calls "close reading" which he 
defines as an "exercise" (p. 61) that looks into a text, isolates it from other texts "in the first instance", in "the hope that we emerge with a clearer understanding of the examined text" (p. 69). What, in practice, does this amount to? He extracts some paragraphs, numbers the sentences and proceeds systematically to outline the language, the connections and the unfolding argument. One application of this is to the well-known passage in Book III of A treatise of human nature on the origin of justice, where three paragraphs (Hume 2002 [1739-1740], III.2.2.1-3) are supplied and followed by six pages of commentary. Some relaxations from "closeness" occur (a case perhaps of going beyond "the first instance") when references to other Humean texts are invoked and there are frequent asides to Adam Smith. In fact these are made not only here but throughout the book, including some pages on Smith's "four-stages" theory (in the context of enquiry as to whether Hume has a stadial theory; answer "not really" (Henderson 2010, 186ff.).

Albeit that it is undertaken intelligently and not without insight, there are a number of problems with this "method" both extrinsically in execution and intrinsically as a method. Confining these remarks to the "justice" passage mentioned above, in its execution the commentary inserts comparisons that either are unhelpful, as when it is simply stated that Hobbes is Hume's target (p. 83), since we are given no explanation of why this is (disputably) the case, or are simply ad hoc, as when Pufendorf is quoted-from John Stewart (p. 194n.). Another insertion oversimplifies when it is claimed that "selfishness" is "the" source of justice, property and government (p. 85), especially since a few pages later Hume is quoted identifying "scanty provision" as another source. Henderson does talk of "scarcity" but the issue is rather that, for a close reader, it is surprising that he does not comment on the meaning of Hume's actual wording here which refers to "selfishness and confin'd generosity", since the force of the latter phrase needs exploring, bearing as it does on Hume's view of familial relations (on which Henderson does comment).

Two other problems are possibly of more moment. Henderson moves very swiftly over one of the most contested aspects of Hume, namely, his "restriction" of justice to property relations (p. 86). What is at stake here is not so much the contestation as an implication of Henderson's own methodology. Arguably the meaning of Hume's reduction of justice to property relations lies principally in what he does not say in the text. Justice for Hume is properly expressed in inflexible 
rules and he does not discuss the commonly held (both historically and contemporaneously) wider, less restricted, notion that equates justice with a general code of conduct characteristic of Aristotelian/Natural Law ethics-witness Hutcheson's declaration that the highest branch of justice is piety to God (Hutcheson 2007 [1747], I, 8). For Hume this latter approach would introduce flexibility and "infinite confusion in human society" (Hume 2002 [1739-1740], III.2.6.9). This has direct bearing on Hume's "economics" since stability of possession is a prerequisite. In short, that Hume is deliberately distancing himself from key prevalent arguments is not derivable merely from close reading, notwithstanding the "relevance" of such distancing to an appreciation of the "foundation" (Henderson 2010, 68, 91) of Hume's economics in A treatise of human nature.

The remaining problem in this exemplifying passage bears on the book's aim. After the exercise in close reading Henderson proceeds to note aspects from elsewhere in that chapter of A treatise of human nature that he has not analysed, including questions of economic motivation, the development of "new wants", the free rider problem, the emergence of money, and so on. For a book designed "to help those coming new to the study of Hume" (p. 32), it might be reasonably thought that a fuller treatment of these issues was in order. Nor is this an isolated occurrence. In the chapter most explicitly devoted to the "economics" Henderson is explicit that his focus is on money-he considers closely, in addition to "Of money", "Of interest", "Of the balance of trade" and "Of public credit" (in an earlier chapter he had treated similarly "Of commerce" and in his final chapter on Hume on progress he deals with "Of the populousness of ancient nations")-and advises the reader to look elsewhere for "issues not here dealt with" and for "wider" discussion (p. 141). At the very least, this selectiveness sits awkwardly with the book's intent.

While still upholding paragraph by paragraph "internal" reading (p. 141) Henderson's later discussion is less abstemious with external sources. For example, he is not averse to throwing in passing references to Aristotle and Locke on moral limits to accumulation (p. 115) or, in the context of debates about interest, to referring to Locke, Petty, and Massie (p. 151) or to invoking the names of "late mercantilists" like Defoe, Davenant, and Postlethwayt (p. 139). Regarding this last example, if a reader was looking for a line on Hume and mercantilism they would be disappointed since we are given a mix of interpretative statements, 
such as that Hume is offering a "direct challenge" in his definition of money while "mercantilist ideas permeate of commerce" (p. 137). It is not, of course, that Hume has to be consistent but that the intended reader would not be helped much by such a range of judgements.

These "external" references betray an uneasy attitude toward context. Henderson's commitment to close reading produces claims that "whatever the wider context" the analysis "has shown" how Hume's "economics thinking"-the structure of its writing and its development-is related to A treatise of human nature and the Enquiries (p. 150). Against this he states that Hume's "economic concerns" need "to be read in context" (p. 140) and, more substantively, he interpolates at one point that "Hume is writing in the context of the recoinage debate" (p. 148). However, the reader is given no more information and is left little wiser. There is, indeed a disarming footnote where he declares that though this is an "internal" study it is "appropriate to look at outside influences from time to time" (p. 199). The reference here is to Joshua Gee and, seemingly running counter to the statement on page 69 quoted above, it is justified by the claim that a comparison "will help secure an understanding of the advantages of Hume's approach" (p. 155). Gee is at least cited by Hume, but Henderson also includes some pages on Hume's relation to Cantillon (p. 163ff.). This context, however, is generated by inconsequential commentary and pace Henderson it would be very possible to omit this.

One point made in the assessment of the Hume-Cantillon issue is that they were working in different genres and this intimates a pervasive theme in the book. The strongest aspect of the book is the discussion of Hume's attentiveness to his audience following the perceived failure of A treatise of human nature to gain a readership, and his corresponding "communicative strategies" thereafter. Henderson makes a particularly enlightening point about Hume's use of the essay format to forestall the difficulties attendant upon a "long chain of reasoning" (see pp. 42, 94, 118, et passim). (Compare Hume's reference to "compleat chain" in the Advertisement to A treatise of human nature with the remark at the outset of "Of commerce", that Henderson quotes (p. 133), that arguments ought not to be drawn "too fine or connect too long a chain of consequences together".) This change is implicitly a case of the "rhetorical turn" but, despite being trailed in the opening pages, the meaning of this term is not explicitly discussed at any length. What seems to pass for that discussion are references to Cicero. 
These themselves are not systematic. Not surprisingly, and reasonably enough given there is not "world enough and time", no effort is made to identify Cicero's particular influence and there is a tendency to fall back on locutions like "to some extent" (pp. 122, 130) or "in a sense" (p. 127) and to remark "it is interesting" (pp. 103, 106, 115). At times this does produce near meaningless comments like it is a "possible link" that both Hume and Cantillon had read Cicero (p. 199n.). Notwithstanding such platitudes Henderson's line is helpful, as, with specific reference to the "economics", it builds, with acknowledgment, on Box's work.

My final set of remarks pertain to why "economics" is in scarequotes. Henderson takes a relaxed attitude to the definition, saying at one point that he is interpreting "economic ideas" "fairly widely" (p. 68, and see p. 99) and refers to "essays conventionally classified as economic" (p. 127). Within this width there is some narrowing. Hence despite being a fairly obvious subject, the essay "Of taxes" is not treated at all while "Of refinement in arts" is only dealt with in passing, nor, perhaps less obviously, is "Of national characters" considered despite Henderson's emphasis on causal analysis as a continuing thread in Hume. At times, too, he plays fast and loose with relation to the "political". While admitting that Hume's "economic concerns" are "politically located" (p. 140) he also judges that Rotwein "correctly" excluded "Of balance of power" from his list of Hume's economic essays (p. 154).

In sum, this book does not offer anything especially novel or controversial regarding the substance of Hume's arguments. In a book not designed for an advanced readership that is not an issue, but what is amiss is the means of delivery. It is for that reason that this review has focused on Henderson's methodology. The book is something of a missed opportunity. Its unevenness, and selectivity, of content means it does not a fill what is a real gap, namely, the provision of a nonsophisticated review of Hume's economics.

Alas, I cannot conclude without observing that the book is marred by sloppy editing. There are frequent mis-spellings (e.g., "Malebranch", "Berkley"), typos some of which make sentences gibberish (e.g., p. 38) or which confuse (e.g., "casual" for "causal", p. 151) as well as an egregious misquotation ("collabourate" instead of "corroborate" from A treatise of human nature, p. 43). Some redemption may be found in a good index. 


\section{REFERENCES}

Box, Mark A. 1990. The suasive art of David Hume. Princeton: Princeton University Press.

Hume, David. 1987 [1752]. Political discourses. Reprinted in David Hume essays: moral, political, and literary, ed. Eugene F. Miller. Indianapolis: Liberty Press.

Hume, David. 2002 [1739-1740]. A treatise of human nature. Eds. David F. Norton, and Mary J. Norton. Oxford: Oxford University Press.

Hume, David. 1999 [1748]. An enquiry concerning human understanding. Ed. Tom L. Beauchamp. Oxford: Oxford University Press.

Hume, David. 1998 [1751]. An enquiry concerning the principles of morals. Ed. Tom L. Beauchamp. Oxford: Oxford University Press.

Hutcheson, Francis. 2007 [1747]. A short introduction to moral philosophy. Ed. Luigi Turco. Indianapolis: Liberty Press.

Christopher J. Berry is professor of political theory at the University of Glasgow. Among his books are David Hume (Continuum, 2009) and Social Theory of the Scottish Enlightenment (Edinburgh, 1997) and he is currently editing a volume of essays on Adam Smith for Oxford University Press. He is an elected member of Scotland's National Academy, The Royal Society of Edinburgh.

Contact e-mail: <Christopher.Berry@glasgow.ac.uk> 